\title{
PENERAPAN MODEL PEMBELAJARAN TUNTAS DALAM MENINGKATKAN MOTIVASI BELAJAR PENDIDIKAN AGAMA ISLAM PADA SISWA KELAS IV SD
}

\author{
Suharti \\ Guru SDN 22 Penjalaan Kayong Utara
}

\begin{abstract}
Abstrak : Belajar memerlukan keterlibatan mental dan kerja siswa sendiri. Penjelasan dan pemeragaan semata tidak akan membuahkan hasil belajar yang langgeng. Biasanya yang bisa membuahkan hasil belajar yang langgeng hanyalah kegiatan belajar aktif. Agar belajar menjadi aktif siswa harus mengerjakan banyak sekali tugas. Mereka harus menggunakan otak, mengkaji gagasan, memecahkan masalah, dan menerapkan apa yang mereka pelajari. Belajar aktif harus gesit, menyenangkan, bersemangat dan penuh gairah. Siswa bahkan sering meninggalkan tempat duduk mereka, bergerak leluasa dan berfikir keras (moving about dan thinking aloud) Masalah dalam penelitian ini adalah bagaimanakah pengaruh model pembelajaran tuntas dalam meningkatkan motivasi belajar Pendidikan Agama Islam pada siswa Kelas IV SDN 22 Penjalaan Kecamatan Simpang Hilir Kabupaten Kayong Utara. Untuk meningkatkan prestasi dan motivasi siswa dalam belajar Pendidikan Agama Islam, khususnya di SDN 22 Penjalaan Kecamatan Simpang Hilir Kabupaten Kayong Utara, salah satunya yaitu dengan menerapkan model pembelajaran tuntas. Dengan menerapkan model pembelajaran ini diharapkan prestasi serta motivasi belajar Pendidikan Agama Islam dapat meningkat. Setelah melalu penelitian tindakan kelas dengan menggunakan model pembelajaran tuntas terbukti dapat meningkatkan kualitas pembelajaran Pendidikan Agama Islam, hal ini terlihat dengan terjadinya peningkatan ketuntasan belajar siswa dalam setiap siklus, yaitu siklus I $(66,67 \%)$, siklus II (75,56\%), siklus III (86,67\%).
\end{abstract}

Kata Kunci : Model, Pembelajaran, Tuntas

\section{PENDAHULUAN}

Menurut teori psikologi, anak yang rasional selalu bertindak sesuai tingkatan perkembangan umur mereka. Ia mengadakan reaksi - reaksi terhadap lingkungannya, atau adanya aksi dari lingkungan maka ia melakukan kegiatan atau aktivitas. Dalam pendidikan kuno aktivitas anak tidak pernah diperhatikan karena menurut pandangan mereka anak dilahirkan tidak lain sebagai "orang dewasa dalam bentuk kecil". Ia harus diajarkan menurut kehendak orang dewasa. Karena itu ia harus menerima dan mendengar apa-apa yang diberikan dan disampaikan orang dewasa/guru tanpa dikritik. Anak tak obahnya seperti gelas kosong yang pasif menerima apa saja yang dituangkan ke dalamnya.

Pandangan yang lebih maju (modern) menganggap hal tersebut di atas sesuatu yang keterlaluan, menyiksa serta mengingkari harkat kemanusiaan anak. Aliran modern ini merombak dan mengubah pandangan itu dan mengantikannya dengan penekanan pada kegiatan anak dalam proses pembelajaran. Anak aktif mencari sendiri dan bekerja sendiri. dengan demikian anak akan lebih bertanggung jawab dan berani mengambil keputusan sehingga pengertian mengenai suatu persoalan benar-benar mereka pahami dengan baik. Walaupun mereka mengambil keputusan sendiri berdasarkan 
pertimbangan kata hatinya, namun putusan mereka tersebut berhubungan juga dengan masyarakat, sebab individu itu baru berarti kalau ia telah berada dalam masyarakat.

Di dalam proses belajar-mengajar, guru harus memiliki strategi, agar siswa dapat belajar secara efektif dan efisien, mengena pada tujuan yang diharapkan. Salah satu langkah untuk memiliki strategi itu ialah harus menguasai teknik-teknik penyajian, atau biasanya disebut metode mengajar.

Teknik penyajian pelajaran adalah suatu pengetahuan tentang cara-cara mengajar yang digunakan oleh guru atau instrukstur. Pengertian lain ialah sebagai teknik penyajian yang dikuasai oleh guru untuk mengajar atau menyajikan bahan pelajaran kepada siswa di dalam kelas, agar pelajaran tersebut dapat ditangkap, dipahami dan digunakan oleh siswa dengan baik. Di dalam kenyataan cara atau metode mengajar atau teknik penyajian yang digunakan guru untuk menyampaikan informasi atau massage lisan kepada siswa berbeda dengan cara yang ditempuh untuk memantapkan siswa dalam menguasai pengetahuan, keterampilan serta sikap. Metode yang digunakan untuk memotivasi siswa agar mampu menggunakan pengetahuannya untuk memecahkan suatu masalah yang dihadapi ataupun untuk menjawab suatu pertanyaan akan berbeda dengan metode yang diguanakan untuk tujuan agar siswa mampu berpikir dan mengemukakan pendapatnya sendiri di dalam menghadapi segala persoalan.

Kita mengenal bermacam-macam teknik penyajian dari yang tradisional, yang digunakan sejak dahulu kala, tetapi juga yang modern, yang digunakan baru akhir-akhir ini saja.

Perkembangan selanjutnya para ahli masih terus mengadakan penelitian dan eksperimen agar dapat menemukan teknik penyajian yang dipandang paling efektif untuk pelajaran tertentu. apakah hal itu akan terjawab, kita serahkan pada hasil penelitian para ahli tersebut.

Dari bermacam-macam teknik mengajar yaitu ada yang menekankan peranan guru yang utama dalam pelaksanaan penyajian, tetapi ada pula yang menekankan pada media hasil teknologi moderen seperti televis, radio, kasset, video-tape, film, head-projector, mesin-belajar dan lain-lain, bahkan telah menggukanan bantuan satelit. Ada pula teknik penyajian yang hanya digunakan untuk sejumlah siswa yang terbatas, tetapi ada pula yang digunakan untuk sejumlah siswa yang tidak terbatas.

Metode mengajar yang guru gunakan dalam setiap kali pertemuan di kelas bukanlah asal pakai, tetapi setelah melalui seleksi yang berkesesuaian dengan perumusan tujuan intruksional khusus. Sebab dalam kegiatan belajar mengajar, mengajar bukan semata persoalan menceritakan. Belajar bukanlah konsekuensi otomatis dari perenungan informasi ke dalam benak siswa. Belajar memerlukan keterlibatan mental dan kerja siswa sendiri. Penjelasan dan pemeragaan semata tidak akan membuahkan hasil belajar yang langgeng. Yang bisa membuahkan hasil belajar yang langgeng hanyalah kegiatan belajar aktif.

Agar belajar menjadi aktif siswa harus mengerjakan banyak sekali tugas. Mereka harus menggunakan otak, mengkaji gagasan, memecahkan masalah, dan menerapkan apa yang mereka pelajari. Belajar aktif harus gesit, menyenangkan, bersemangat dan penuh gairah. Siswa bahkan sering meninggalkan tempat duduk mereka, bergerak leluasa dan berfikir keras (moving about dan thinking aloud)

Untuk bisa mempelajari sesuatu dengan baik, kita perlu mendengar, melihat, mengajukan pertanyaan tentangnya, dan membahasnya dengan orang lain. Bukan cuma itu, siswa perlu "mengerjakannya", yakni menggambarkan sesuatu dengan cara mereka sendiri, menunjukkan contohnya, mencoba 
mempraktekkan keterampilan, dan mengerjakan tugas yang menuntut pengetahuan yang telah atau harus mereka dapatkan.

Dengan menyadari gejala-gejala atau kenyataan tersebut diatas, maka dalam penelitian ini penulis mengambil judul "Meningkatkan Prestasi Belajar Pendidikan Agama Islam Dengan Menerapkan Model Pengajaran Tuntas Pada Siswa Kelas IV SDN 22 Penjalaan Kecamatan Simpang Hilir Kabupaten Kayong Utara Tahun Pelajaran 2016/2017."

Bertitik tolak dari latar belakang diatas maka penulis merumuskan permasalahnnya sebagi berikut: (1) Apakah penerapan model pembelajaran tuntas dapat meningkatkan prestasi siswa terhadap materi pelajaran Pendidikan Agama Islam pada siswa Kelas IV SDN 22 Penjalaan Kecamatan Simpang Hilir Kabupaten Kayong Utara. (2) Bagaimanakah pengaruh model pembelajaran tuntas dalam meningkatkan motivasi belajar Pendidikan Agama Islam pada siswa Kelas IV SDN 22 Penjalaan Kecamatan Simpang Hilir Kabupaten Kayong Utara.

Untuk meningkatkan prestasi dan motivasi siswa dalam belajar Pendidikan Agama Islam, khususnya di SDN 22 Penjalaan Kecamatan Simpang Hilir Kabupaten Kayong Utara, salah satunya yaitu dengan menerapkan model pembelajaran tuntas. Dengan menerapkan model pembelajaran ini diharapkan prestasi serta motivasi belajar Pendidikan Agama Islam dapat meningkat.

Sesuai dengan permasalahan di atas, penelitian ini bertujuan untuk: (1) Ingin mengetahui bagaimanakah peningkatan prestasi belajar Pendidikan Agama Islam setelah diterapkannya model pembelajaran tuntas pada siswa. (2) Ingin mengetahui pengaruh model pembelajaran tuntas dalam meningkatkan prestasi dan motivasi belajar terhadap materi pelajaran Pendidikan Agama Islam setelah diterapkan model pembelajaran tuntas.
Adapun maksud penulis mengadakan penelitian ini diharapkan dapat berguna sebagai: (1) Memberikan informasi tentang model pembelajaran yang sesuai dengan proses belajar-mengajar Pendidikan Agama Islam. (2) Meningkatkan prestasi dan motivasi pada pelajaran Pendidikan Agama Islam. (3) Menambah pengetahuan dan wawasan penulis tentang peranan guru Pendidikan Agama Islam dalam meningkatkan pemahaman siswa belajar Pendidikan Agama Islam. (4) Sebagai penentu kebijakan dalam upaya meningkatkan prestasi belajar siswa khususnya pada mata pelajaran Pendidikan Agama Islam. (5) Menerapkan metode yang tepat sesuai dengan materi pelajaran Pendidikan Agama Islam.

Pengertian belajar sudah banyak dikemukakan dalam kepustakaan. Yang dimaksud belajar yaitu perbuatan murid dalam bidang material, formal serta fungsional pada umumnya dan bidang intelektual pada khususnya. Jadi belajar merupakan hal yang pokok. Belajar merupakan suatu perubahan pada sikap dan tingkah laku yang lebih baik, tetapi kemungkinan mengarah pada tingkah laku yang lebih buruk.

Untuk dapat disebut belajar, maka perubahan harus merupakan akhir dari pada periode yang cukup panjang. Berapa lama waktu itu berlangsung sulit ditentukan dengan pasti, tetapi perubahan itu hendaklah merupakan akhir dari suatu periode yang mungkin berlangsung berhari-hari, berminggu-minggu, berbulan-bulan atau bertahun-tahun. Belajar merupakan suatu proses yang tidak dapat dilihat dengan nyata proses itu terjadi dalam diri seseorang yang sedang mengalami belajar. Jadi yang dimaksud dengan belajar bukan tingkah laku yang nampak, tetapi prosesnya terjadi secara internal di dalam diri individu dalam mengusahakan memperoleh hubunganhubungan baru.

Sebelum dijelaskan pengertian mengenai prestasi belajar, terlebih dahulu 
akan dikemukakan tentang pengertian prestasi. Prestasi adalah hasil yang telah dicapai. Dengan demikian bahwa prestasi merupakan hasil yang telah dicapai oleh seseorang setelah melakukan sesuatu pekerjaan/aktivitas tertentu.

Jadi prestasi adalah hasil yang telah dicapai setiap individu dengan adanya belajar hasilnya dapat dicapai. Setiap individu belajar menginginkan hasil yang yang sebaik mungkin. Oleh karena itu setiap individu harus belajar dengan sebaik-baiknya supaya berprestasi dengan baik. Sedang pengertian prestasi juga ada yang mengatakan bahwa prestasi adalah kemampuan. Kemampuan di sini berarti keahlian individu dalam mengerjakan sesuatu.

Untuk memperoleh prestasi/hasil belajar yang baik harus dilakukan dengan baik dan pedoman cara yang tepat. Setiap orang mempunyai cara atau pedoman sendiri-sendiri dalam belajar. Pedoman/cara yang satu cocok digunakan oleh seorang siswa, tetapi mungkin kurang sesuai untuk anak/siswa yang lain. Hal ini disebabkan karena mempunyai perbedaan individu dalam hal kemampuan, kecepatan dan kepekaan dalam menerima materi pelajaran.

Oleh karena itu tidaklah ada suatu petunjuk yang pasti yang harus dikerjakan oleh seorang siswa dalam melakukan kegiatan belajar. Tetapi faktor yang paling menentukan keberhasilan belajar adalah para siswa itu sendiri. Untuk dapat mencapai hasil belajar yang sebaikbaiknya harus mempunyai kebiasaan belajar yang baik.

Belajar tuntas merupakan model pembelajaran yang dapat dilaksanakan di dalam kelas, dengan asumsi bahwa di dalam kondisi yang tepat semua peserta didik akan mampu belajar dengan baik dan memperoleh hasil belajar secara maksimal terhadap seluruh bahan yang dipelajari (Ramayulis, 2005:193).

Berdasarkan uraian di atas, maka model belajar tuntas akan terlaksana apabila, (1) siswa menguasai semua bahan pelajaran yang disajikan secara penuh, (2) bahan pengajaran dibetulkan secara sistematis.

Dalam proses pembelajaran dimungkinkan bagi guru untuk menetapkan tingkat penguasaan yang diharapkan dari setiap peserta didik dengan menyediakan berbagai kemungkinan belajar dan meningkatan mutu pembelajaran. Guru harus mempu meyakinkan bahwa setiap peserta didik dapat mencapai penguasaan penuh dalam belajar.

Menurut Carrol (dalam Ramayulis 2005:193) pada dasarnya bakat merupakan indeks kemampuan seseorang, melainkan sebagai ukuran kecepatan belajar (measures of learning rate). Artinya seorang yang memiliki bakat tinggi memerlukan waktu relatif sedikit untuk mencapai taraf penguasaan bahan dibandingkan dengan peserta didik yang memiliki bakat rendah. Dengan demikian peserta didik dapat mencapai penguasaan penuh terhadap bahan yang disajikan, bila kualitas pembelajaran dan kesempatan waktu belajar dibuat tepat sesuai dengan kebutuhan masing-masing peserta didik.

Berdasarkan uraian di atas maka model belajar dilandasi oleh dua asumsi yaitu: (1) Bahwa adanya korelasi antara tingkat keberhasilan dengan kemampuan potensial (bakat). Hal ini dilandasi teori tentang bakat yang dikemukakan oleh Carrol yang menyatakan bahwa apabila para peserta didik didistibusikan secara normal dengan memperhatikan kemampuannya secara potensial untuk beberapa bidang pengajaran, kemudian mereka diberi pengajaran yang sama dan hasil belajarnya diukur, ternyata akan menunjukkan distribusi normal. Hal ini berarti bahwa peserta didik yang berbakat cenderung untuk memperoleh nilai tinggi (Ramayulis,194:1990). (2) Apabila dilaksanakan secara sistematis, maka semua peserta didik akan mampu menguasai bahan yang disajikan kepadanya. 
Menurut Benyamin S. Bloom (Ramayulis,194:1990) ada beberapa langkah yang harus dilakukan dalam belajar tuntas yaitu: (1) Menentukan unit pelajaran (dipecah untuk setiap satu dua minggu). (2) Merumuskan tujuan pengajaran (secara khusus dan terukur).(3) Menentukan standar ketuntasan (patokan berupa persentase). (4) Menyusun dianostik test, test formatif sebagai dasar umpan balik. (5) Mempersiapkan perangkat tugas untuk dipelajari.

\section{METODE}

Penelitian ini merupakan penelitian tindakan (action research), karena penelitian dilakukan untuk memecahkan masalah pembelajaran di kelas. Penelitian ini juga termasuk penelitian deskriptif, sebab menggambarkan bagaimana suatu teknik pembelajaran diterapkan dan bagaimana hasil yang diinginkan dapat dicapai.

Menurut Sukidin dkk. (2002:54) ada 4 macam bentuk penelitian tindakan, yaitu: (1) penelitian tindakan guru sebagai peneliti, (2) penelitian tindakan kolaboratif, (3) penelitian tindakan simultan terintegratif, dan (4) penelitian tindakan sosial eksperimental.

Keempat bentuk penelitian tindakan di atas, ada persamaan dan perbedaannya. Menurut Oja dan Smulyan sebagaimana dikutip oleh Kasbolah, (2000) (dalam Sukidin, dkk. 2002:55), ciri-ciri dari setiap penelitian tergantung pada: (1) tujuan utamanya atau pada tekanannya, (2) tingkat kolaborasi antara pelaku peneliti dan peneliti dari luar, (3) proses yang digunakan dalam melakukan penelitian, dan (4) hubungan antara proyek dengan sekolah.

Tujuan utama penelitian tindakan kelas ialah untuk meningkatkan praktikpraktik pembelajaran di kelas. Dalam kegiatan ini, guru terlibat langsung secara penuh dalam proses perencanaan, tindakan, observasi, dan refleksi. Kehadiran pihak lain dalam penelitian ini peranannya tidak dominan dan sangat kecil.

Penelitian ini mengacu pada perbaikan pembelajaran yang berkesinambungan. Kemmis dan Taggart (1988:14) menyatakan bahwa model penelitian tindakan adalah berbentuk spiral. Tahapan penelitian tindakan pada suatu siklus meliputi perencanaan atau pelaksanaan observasi dan refleksi. Siklus ini berlanjut dan akan dihentikan jika sesuai dengan kebutuhan dan dirasa sudah cukup.

Penelitian ini terbagi beberapa siklus, dimana setiap siklus meliputi planning (rencana), action (tindakan), observation (pengamatan), dan reflection (refleksi). Langkah pada siklus berikutnya adalah perencanaan yang sudah direvisi, tindakan, pengamatan, dan refleksi. Sebelum masuk pada siklus 1 dilakukan tindakan pendahuluan berupa identifikasi permasalahan. Siklus spiral dari tahaptahap penelitian tindakan kelas dapat dilihat pada gambar berikut:

Penelitian ini bertempat di SDN 22 Penjalaan Kecamatan Simpang Hilir Kabupaten Kayong Utara tahun pelajaran 2016/2017 dan dilaksanakan pada bulan April semester genap tahun pelajaran 2016/2017, dengan subyek penelitian adalah siswa-siswi Kelas IV SDN 22 Penjalaan Kecamatan Simpang Hilir Kabupaten Kayong Utara pada pokok bahasan kisah-kisah Nabi.

Penelitian ini dilaksanakan melalui 5 tahap, yaitu, (a) tahap perencanaan, (b) persiapan, (c) pelaksanaan, (d) pengolahan data, dan (e) penyusunan Laporan

\section{HASIL PENELITIAN DAN PEMBAHASAN}

Data penelitian yang diperoleh berupa data observasi berupa pengamatan pengelolaan model pembelajaran tuntas dan pengamatan aktivitas siswa dan guru pada akhir pembelajaran, dan data tes formatif siswa pada setiap siklus.

Data lembar observasi diambil dari dua pengamatan yaitu data pengamatan 
pengelolaan model pembelajaran tuntas yang digunakan untuk mengetahui pengaruh penerapan model pembelajaran tuntas dalam meningkatkan prestasi belajar siswa dan data pengamatan aktivitas siswa dan guru.

Data tes formatif untuk mengetahui peningkatan prestasi belajar siswa setelah diterapkan proses belajar mengajar dengan menerapkan model pembelajaran tuntas.

\section{Peneltian Tindakan Siklus I}

Pelaksanaan kegiatan belajar mengajar untuk siklus I dilaksanakan pada tanggal 2 Maret 2017 di Kelas IV dengan jumlah siswa 45 siswa. Dalam hal ini peneliti bertindak sebagai pengajar, sedangkan yang bertindak sebagai pengamat adalah kepala sekolah dengan dibantu seorang guru. Adapun proses belajar mengajar mengacu pada rencana pelajaran yang telah dipersiapkan. Pengamatan (observasi) dilaksanakan bersamaan dengan pelaksaaan belajar mengajar.

Pada akhir proses belajar mengajar siswa diberi tes formatif I dengan tujuan untuk mengetahui tingkat keberhasilan siswa dalam proses belajar mengajar yang telah dilakukan. Adapun data hasil penelitian pada siklus I adalah sebagai berikut:

Tabel 1

Pengelolan Pembelajaran Pada Siklus I

\begin{tabular}{|c|c|c|c|c|}
\hline \multirow[t]{2}{*}{ No } & \multirow[t]{2}{*}{ Aspek yang diamati } & \multicolumn{2}{|c|}{ Penilaian } & \multirow{2}{*}{$\begin{array}{l}\text { Rata- } \\
\text { rata }\end{array}$} \\
\hline & & P1 & $\mathbf{P 2}$ & \\
\hline \multirow[t]{15}{*}{ I } & Pengamatan KBM & & & \\
\hline & A. Pendahuluan & & & \\
\hline & 1. Memotivasi siswa & 2 & 2 & 2 \\
\hline & 2. Menyampaikan tujuan pembelajaran & 2 & 2 & 2 \\
\hline & B. Kegiatan Inti & & & \\
\hline & $\begin{array}{l}\text { 1. Mendiskusikan langkah-langkah kegiatan } \\
\text { bersama siswa }\end{array}$ & 3 & 3 & 3 \\
\hline & 2. Membimbing siswa melakukan kegiatan & & & \\
\hline & 3. Membimbing siswa mendiskusikan hasil & 3 & 3 & 3 \\
\hline & kegiatan dalam kelompok & 3 & 3 & 3 \\
\hline & $\begin{array}{l}\text { 4. Memberikan kesempatan pada siswa untuk } \\
\text { mempresentasikan hasil penyelidikan }\end{array}$ & 3 & 3 & 3 \\
\hline & 5. Membimbing siswa merumuskan & & & \\
\hline & kesimpulan/menemukan konsep & 3 & 3 & 3 \\
\hline & C. Penutup & & & \\
\hline & 1. Membimbing siswa membuat rangkuman & 3 & 3 & 3 \\
\hline & 2. Memberikan evaluasi & 3 & 3 & 3 \\
\hline II & Pengelolaan Waktu & 2 & 2 & 2 \\
\hline \multirow[t]{4}{*}{ III } & Antusiasme Kelas & & & \\
\hline & 1. Siswa Antusias & 2 & 2 & 2 \\
\hline & 2. Guru Antusias & 3 & 3 & 3 \\
\hline & Jumlah & 32 & 32 & 32 \\
\hline
\end{tabular}

Keterangan :

1 : Tidak Baik

2 : Kurang Baik

3 : Cukup Baik

4 : Sangat Baik 
Berdasarkan tabel di atas aspek-aspek yang mendapatkan kriteria kurang baik adalah memotivasi siswa, menyampaikan tujuan pembelajaran, pengelolaan waktu, dan siswa antusias. Keempat aspek yang mendapat penilaian kurang baik di atas, merupakan suatu kelemahan yang terjadi pada siklus I. Dan akan dijadikan bahan kajian untuk refleksi dan revisi yang akan dilakukan pada siklus II.

Hasil observasi berikutnya adalah aktivitas guru dan siswa seperti pada tabel berikut.

Tabel 2

Aktivitas Guru Pada Siklus I

\begin{tabular}{clc}
\hline No & \multicolumn{1}{c}{ Aktivitas Guru yang diamati } & Persentase \\
\hline 1 & Menyampaikan tujuan & 7,81 \\
2 & Memotivasi siswa/merumuskan masalah & 7,81 \\
3 & Mengkaitkan dengan pelajaran berikutnya & 7,81 \\
4 & Menyampaikan materi/langkah-langkah/strategi & 9,38 \\
5 & Menjelaskan materi yang sulit & 12,50 \\
6 & Membimbing dan mengamati siswa dalam menemukan & 20,31 \\
7 & konsep & 9,38 \\
8 & Meminta siswa menyajikan dan mendiskusikan hasil & 17,19 \\
9 & kegiatan & 7,81 \\
& Memberikan umpan balik & \\
& Membimbing siswa merangkum pelajaran & \\
\hline
\end{tabular}

Berdasarkan tabel di atas tampak dengan sesama siswa, diskusi antar siswa, bahwa aktivitas guru yang paling dominan siswa dengan guru, dan membaca buku pada siklus I adalah membimbing dan yaitu masing-masing 17,58\% 13,48 dan mengamati siswa dalam menemukan $10,74 \%$.

konsep yaitu 20,31\%. Aktivitas lain yang Pada siklus I, secara garis besar persentasenya cukup besar adalah kegiatan belajar mengajar dengan model memberi umpan balik/evaluasi/tanya pembelajaran tuntas sudah dilaksanakan jawab dan menjelaskan materi yang sulit dengan baik, walaupun peran guru masih yaitu masing-masing sebesar $17,19 \%$ dan cukup dominan untuk memberikan $12,50 \%$. Sedangkan aktivitas siswa yang penjelasan dan arahan karena model paling dominan adalah mengerjakan/memperhatikan penjelasan guru yaitu 21,09\%. Aktivitas lain yang persentasenya cukup besar adalah bekerja tersebut masih dirasakan baru oleh siswa.

Berikutnya adalah rekapitulasi hasil tes formatif siswa seperti terlihat pada tabel berikut.

Tabel 3

Rekapitulasi Hasil Tes Formatif Siswa Pada Siklus I

\begin{tabular}{clc}
\hline No & \multicolumn{1}{c}{ Uraian } & Hasil Siklus I \\
\hline 1 & Nilai rata-rata tes formatif & 68,22 \\
2 & Jumlah siswa yang tuntas belajar & 30 \\
3 & Persentase ketuntasan belajar & 66,67 \\
\hline
\end{tabular}

Dari tabel di atas dapat dijelaskan bahwa pada siklus pertama secara klasikal bahwa dengan menerapkan model siswa belum tuntas belajar, karena siswa pembelajaran tuntas diperoleh nilai rata- yang memperoleh nilai $\geq 65$ hanya sebesar rata prestasi belajar siswa adalah $68,22 \quad 66,67 \%$ lebih kecil dari persentase dan ketuntasan belajar mencapai 66,67\% ketuntasan yang dikehendaki yaitu sebesar atau ada 30 siswa dari 45 siswa sudah $85 \%$. Hal ini disebabkan karena siswa tuntas belajar. Hasil tersebut menunjukkan masih merasa baru dan belum mengerti 
apa yang dimaksudkan dan digunakan guru dengan menerapkan model pembelajaran tuntas.

\section{Siklus II}

Pada akhir proses belajar mengajar siswa diberi tes formatif II dengan tujuan untuk mengetahui tingkat keberhasilan siswa dalam proses belajar mengajar yang telah dilakukan. Instrumen yang digunakan adalah tes formatif II. Adapun data hasil penelitian pada siklus II adalah sebagai berikut:

Tabel 5

Pengelolaan Pembelajaran Pada Siklus II

\begin{tabular}{|c|c|c|c|c|}
\hline \multirow{2}{*}{ No } & \multirow{2}{*}{ Aspek yang diamati } & \multicolumn{2}{|c|}{ Penilaian } & \multirow[t]{2}{*}{ Rata-rata } \\
\hline & & P1 & $\mathbf{P 2}$ & \\
\hline \multirow{15}{*}{ I } & Pengamatan KBM & & & \\
\hline & A. Pendahuluan & & & \\
\hline & 1. Memotivasi siswa & 3 & 3 & 3 \\
\hline & 2. Menyampaikan tujuan pembelajaran & 3 & 4 & 3,5 \\
\hline & B. Kegiatan Inti & & & \\
\hline & $\begin{array}{l}\text { 1. Mendiskusikan langkah-langkah kegiatan } \\
\text { bersama siswa }\end{array}$ & 3 & 4 & 3.5 \\
\hline & 2. Membimbing siswa melakukan kegiatan & 4 & 4 & 4 \\
\hline & 3. Membimbing siswa mendiskusikan hasil & & & \\
\hline & kegiatan dalam kelompok & 4 & 4 & 4 \\
\hline & 4. Memberikan kesempatan pada siswa untuk & 4 & 4 & 4 \\
\hline & 5. Membimbing siswa merumuskan & & & \\
\hline & kesimpulan/menemukan konsep & 3 & 3 & 3 \\
\hline & C. Penutup & & & \\
\hline & 1. Membimbing siswa membuat rangkuman & 3 & 4 & 3,5 \\
\hline & 2. Memberikan evaluasi & 4 & 4 & 4 \\
\hline \multirow[t]{2}{*}{ II } & Pengelolaan Waktu & 3 & 3 & 3 \\
\hline & Antusiasme Kelas & & & \\
\hline \multirow[t]{2}{*}{ III } & 1. Siswa Antusias & 4 & 3 & 3,5 \\
\hline & 2. Guru Antusias & 4 & 4 & 4 \\
\hline & Jumlah & 41 & 43 & 42 \\
\hline
\end{tabular}

Keterangan :

1 : Tidak Baik

2 : Kurang Baik

3 : Cukup Baik

4 : Sangat Baik

Dari tabel diatas, tampak aspekaspek yang diamati pada siklus II yang dilaksanakan oleh guru dengan menerapkan model pembelajaran tuntas mendapatkan penilaian yang cukup baik. Maksudnya dari seluruh penilaian tidak terdapat nilai kurang. Namum demikian penilaian tersebut belum merupakan hasil yang optimal, untuk itu ada beberapa aspek yang

perlu mendapatkan perhatian untuk penyempurnaan penerapan

pembelajaran selanjutnya. Aspekaspek tersebut adalah memotivasi siswa, membimbing siswa merumuskan kesimpulan /menemukan konsep, dan pengelolaan waktu.

Dengan penyempurnaan aspekaspek di atas dalam penerapan model pembelajaran tuntas diharapkan siswa 
dapat menyimpulkan apa yang telah mereka pelajari dan mengemukakan pendapatnya sehingga mereka akan lebih memahami tentang apa yang telah mereka lakukan. Berikut disajikan hasil observasi aktivitas guru dan siswa:

Tabel 6

Aktivitas Guru Pada Siklus II

\begin{tabular}{clc}
\hline No & \multicolumn{1}{c}{ Aktivitas Guru yang diamati } & Persentase \\
\hline 1 & Menyampaikan tujuan & 71,81 \\
2 & Memotivasi siswa/merumuskan masalah & 6,25 \\
3 & Mengkaitkan dengan pelajaran berikutnya & 6,25 \\
4 & Menyampaikan materi/langkah-langkah/strategi & 9,18 \\
5 & Menjelaskan materi yang sulit & 14,06 \\
6 & Membimbing dan mengamati siswa dalam menentukan konsep & 23,34 \\
7 & Meminta siswa menyajikan dan mendiskusikan hasil kegiatan & 10,93 \\
8 & Memberikan umpan balik & 15,63 \\
9 & Membimbing siswa merangkum pelajaran & 6,25 \\
\hline
\end{tabular}

Berdasarkan tabel di atas tampak bahwa aktivitas guru yang paling dominan pada siklus II adalah membimbing dan mengamati siswa dalam menemukan konsep yaitu $23,34 \%$. Jika dibandingkan dengan siklus I, aktivitas ini mengalami peningkatan. Selain itu aktivitas guru yang mengalami peningkatan adalah menjelaskan materi yang sulit sebesar $14,06 \%$. Meminta siwa mendiskusikan dan menyajikan hasil kegiatan 10,93\%.
Disamping itu ada juga aktivitas guru yang mengalami penurunan antara lain memotivasi siswa dan mengaitkan dengan materi sebelumnya masing-masing menjadi $6,25 \%$, memberi umpan balik menjadi $15,63 \%$ dan membimbing siswa merangkum pelajaran menjadi $6,25 \%$

Berikutnya adalah rekapitulasi hasil tes formatif siswa terlihat pada tabel berikut.

Tabel 7

Rekapitulasi Hasil Tes Formatif Siswa Pada Siklus II

\begin{tabular}{clc}
\hline No & \multicolumn{1}{c}{ Uraian } & Hasil Siklus II \\
\hline 1 & Nilai rata-rata tes formatif & 74,67 \\
2 & Jumlah siswa yang tuntas belajar & 34 \\
3 & Persentase ketuntasan belajar & 75,56 \\
\hline
\end{tabular}

Dari tabel di atas diperoleh nilai rata- belajar. Selain itu siswa juga sudah mulai rata prestasi belajar siswa adalah 74,67 dan ketuntasan belajar mencapai $75,56 \%$ atau ada 34 siswa dari 45 siswa sudah tuntas belajar. Hasil ini menunjukkan bahwa pada siklus II ini ketuntasan belajar secara klasikal telah mengalami peningkatan sedikit lebih baik dari siklus I. Adanya peningkatan hasil belajar siswa ini karena setelah guru menginformasikan bahwa setiap akhir pelajaran akan selalu diadakan tes sehingga pada pertemuan berikutnya siswa lebih termotivasi untuk mengerti apa yang dimaksudkan dan dinginkan guru dengan menerapkan model pembelajaran tuntas.

\section{Siklus III}

Pada akhir proses belajar mengajar siswa diberi tes formatif III dengan tujuan untuk mengetahui tingkat keberhasilan siswa dalam proses belajar mengajar yang telah dilakukan. Instrumen yang digunakan adalah tes formatif III. Adapun data hasil penelitian pada siklus III adalah sebagai berikut: 
Tabel 8

Pengelolaan Pembelajaran Pada Siklus III

\begin{tabular}{|c|c|c|c|c|}
\hline \multirow{2}{*}{ No } & \multirow{2}{*}{ Aspek yang diamati } & \multicolumn{2}{|c|}{ Penilaian } & \multirow{2}{*}{$\begin{array}{l}\text { Rata } \\
\text {-rata }\end{array}$} \\
\hline & & P1 & $\mathbf{P 2}$ & \\
\hline \multirow{16}{*}{ I } & Pengamatan KBM & & & \\
\hline & A. Pendahuluan & & & \\
\hline & 1. Memotivasi siswa & 3 & 3 & 3 \\
\hline & 2. Menyampaikan tujuan pembelajaran & 4 & 4 & 4 \\
\hline & B. Kegiatan Inti & & & \\
\hline & 1. Mendiskusikan & & & \\
\hline & bersama siswa & 4 & 4 & 4 \\
\hline & 2. Membimbing siswa melakukan kegiatan & 4 & 4 & 4 \\
\hline & 3. Membimbing siswa mendiskusikan hasil & & & \\
\hline & kegiatan dalam kelompok & 4 & 4 & 4 \\
\hline & $\begin{array}{l}\text { 4. Memberikan kesempatan pada siswa untuk } \\
\text { mempresentasikan hasil peneyelidikan }\end{array}$ & 4 & 3 & 3,5 \\
\hline & 5. Membimbing siswa merumuskan & & & \\
\hline & kesimpulan/menemukan konsep & 3 & 3 & 3 \\
\hline & C. Penutup & & & \\
\hline & 1. Membimbing siswa membuat rangkuman & 4 & 4 & 4 \\
\hline & 2. Memberikan evaluasi & 4 & 4 & 4 \\
\hline \multirow[t]{2}{*}{ II } & Pengelolaan Waktu & 3 & 3 & 3 \\
\hline & Antusiasme Kelas & & & \\
\hline \multirow[t]{2}{*}{ III } & 1. Siswa Antusias & 4 & 4 & 4 \\
\hline & 2. Guru Antusias & 4 & 4 & 4 \\
\hline & Jumlah & 45 & 44 & 44,5 \\
\hline
\end{tabular}

Keterangan :

1 : Tidak Baik

2 : Kurang Baik

3 : Cukup Baik

4 : Sangat Baik

Dari tabel di atas, dapat dilihat aspekaspek yang diamati pada siklus III yang dilaksanakan oleh guru dengan menerapkan model pembelajaran tuntas mendapatkan penilaian cukup baik dari pengamat adalah memotivasi siswa,

membimbing siswa merumuskan kesimpulan/menemukan konsep, dan pengelolaan waktu. Penyempurnaan aspek-aspek diatas dalam menerapkan model pembelajaran tuntas diharapkan dapat berhasil semaksimal mungkin. 
Tabel 9

Aktivitas Guru Pada Siklus III

\begin{tabular}{clc}
\hline No & \multicolumn{1}{c}{ Aktivitas Guru yang diamati } & Persentase \\
\hline 1 & Menyampaikan tujuan & 7,81 \\
2 & Memotivasi siswa/merumuskan masalah & 6,25 \\
3 & Mengkaitkan dengan pelajaran berikutnya & 10,94 \\
4 & Menyampaikan materi/langkah-langkah/strategi & 17,19 \\
5 & Menjelaskan materi yang sulit & 10,94 \\
6 & Membimbing dan mengamati siswa dalam menemukan konsep & 20,31 \\
7 & Meminta siswa menyajikan dan mendiskusikan hasil kegiatan & 6,25 \\
8 & Memberikan umpan balik & 14,06 \\
9 & Membimbing siswa merangkum pelajaran & 6,25 \\
\hline \multicolumn{2}{c}{ jawab menurun } & masing-masing
\end{tabular}

Berdasarkan tabel di atas tampak bahwa aktivitas guru yang paling dominan pada siklus III adalah membimbing dan mengamati siswa dalam menemukan konsep yaitu $20,31 \%$, aspek ini menurun kembali seperti pada siklus I. Sedangkan aktivitas menjelaskan materi yang sulit, meminta siswa menyajikan dan mendiskusikan hasil pembelajaran, memberi umpan balik/evaluasi/tanya menjadi sebesar $10,94 \%, 6,25 \%$, dan $7,81 \%$

Aktivitas lain yang mengalami peningkatan adalah mengaitkan dengan pelajaran sebelumnya dan menyampaikan langkah-langkah strategis masing menjadi $10,94 \%$ dan $17,19 \%$. Adapun aktivitas yang lain tidak mengalami perubahan.

Berikutnya adalah rekapitulasai hasil tes formatif siswa seperti terlihat pada tabel berikut.

Tabel 10

Hasil Tes Formatif Siswa pada Siklus III

\begin{tabular}{clc}
\hline No & \multicolumn{1}{c}{ Uraian } & Hasil Siklus III \\
\hline 1 & Nilai rata-rata tes formatif & 79,78 \\
2 & Jumlah siswa yang tuntas belajar & 39 \\
3 & Persentase ketuntasan belajar & 86,67 \\
\hline
\end{tabular}

Berdasarkan tabel diatas diperoleh nilai rata-rata tes formatif sebesar $79,78 \%$ dan dari 45 siswa yang telah tuntas sebanyak 39 siswa dan 6 siswa belum mencapai ketuntasan belajar. Maka secara klasikal ketuntasan belajar yang telah tercapai sebesar 86,67\% (termasuk kategori tuntas). Hasil pada siklus III ini mengalami peningkatan lebih baik dari siklus II. Adanya peningkatan hasil belajar pada siklus III ini dipengaruhi oleh adanya peningkatan kemampuan guru dalam menerapkan model pembelajaran tuntas sehingga siswa menjadi lebih terbiasa dengan pembelajaran seperti ini

Berdasarkan analisis data, diperoleh aktivitas siswa dalam proses belajar sehingga siswa lebih mudah dalam memahami materi yang telah diberikan.

\section{Pembahasan}

Melalui hasil penelitian ini menunjukkan bahwa model pembelajaran tuntas memiliki dampak positif dalam meningkatkan prestasi belajar siswa. Hal ini dapat dilihat dari semakin mantapnya pemahaman siswa terhadap materi yang disampaikan guru (ketuntasan belajar meningkat dari siklus I, II, dan III) yaitu masing-masing 66,67\%, 75,56\%, dan $86,67 \%$. Pada siklus III ketuntasan belajar siswa secara klasikal telah tercapai.

mengajar dengan menerapkan model pembelajaran tuntas dalam setiap siklus 
mengalami peningkatan. Hal ini berdampak positif terhadap prestasi belajar siswa yaitu dapat ditunjukkan dengan meningkatnya nilai rata-rata siswa pada setiap siklus yang terus mengalami peningkatan.

Berdasarkan analisis data, diperoleh aktivitas siswa dalam proses pembelajaran Pendidikan Agama Islam pada pokok bahasan kisah-kisah Nabi dengan model pembelajaran tuntas yang paling dominan adalah bekerja dengan sesama siswa, mendengarkan /memperhatikan penjelasan guru, dan diskusi antar siswa dan siswa dengan guru. Jadi dapat dikatakan bahwa aktivitas siswa dapat dikategorikan aktif.

Sedangkan untuk aktivitas guru selama pembelajaran telah melaksanakan langkah-langkah kegiatan belajar mengajar dengan menerapkan model pembelajaran tuntas dengan baik. Hal ini terlihat dari aktivitas guru yang muncul di antaranya aktivitas membimbing dan mengamati siswa dalam menemukan konsep, menjelaskan materi yang sulit, memberi umpan balik /evaluasi/tanya jawab dimana persentase untuk aktivitas di atas cukup besar.

\section{KESIMPULAN DAN SARAN}

\section{Simpulan}

$\begin{array}{ccc}\text { Berdasarkan } & \text { dari tujuan } \\ \text { penelitian tindakan kelas } & \text { (action }\end{array}$ research) untuk meningkatkan mutu pembelajaran yang terjadi di kelas, serta berdasarkan hasil penelitian yang telah dipaparkan sebanyak tiga siklus, hasil seluruh pembahasan serta analisis yang telah dilakukan dapat disimpulkan sebagai berikut: (1) Model pembelajaran tuntas dapat meningkatkan kualitas pembelajaran Pendidikan Agama Islam, hal ini terlihat dengan ditandai dengan peningkatan ketuntasan belajar siswa dalam setiap siklus, yaitu siklus I $(66,67 \%)$, siklus II $(75,56 \%)$, siklus III (86,67\%). (2) Model pembelajaran tuntas dapat menjadikan siswa merasa dirinya mendapat perhatian dan kesempatan untuk menyampaikan pendapat, gagasan, ide dan pertanyaan, siswa dapat bekerja secara mandiri maupun kelompok dan mampu mempertanggungjawabkan segala tugas individu maupun kelompok, serta penerapan model pembelajaran tuntas mempunyai pengaruh positif, yaitu dapat meningkatkan motivasi belajar siswa.

\section{Saran}

Dari hasil penelitian yang diperoleh dari uraian sebelumnya agar proses belajar mengajar Pendidikan Agama Islam lebih efektif dan lebih memberikan hasil yang optimal bagi siswa, maka disampaikan saran sebagai berikut: (1) Untuk melaksanakan model pembelajaran tuntas memerlukan persiapan yang cukup matang, sehingga guru harus mampu menentukan atau memilih topik yang benar-benar bisa diterapkan dengan model pembelajaran tuntas dalam proses belajar mengajar sehingga diperoleh hasil yang optimal. (2) Dalam rangka meningkatkan prestasi belajar siswa, guru hendaknya lebih sering melatih siswa dengan berbagai metode pengajaran, walau dalam taraf yang sederhana, dimana siswa nantinya dapat menemukan pengetahuan baru, memperoleh konsep dan keterampilan, sehingga siswa berhasil atau mampu memecahkan masalah-masalah yang dihadapinya. (3) Perlu adanya penelitian yang lebih lanjut, karena hasil penelitian ini hanya dilakukan di SDN 22 Penjalaan Kecamatan Simpang Hilir Kabupaten Kayong Utara tahun pelajaran 2016/2017. (4) Untuk penelitian yang serupa hendaknya dilakukan perbaikan-perbaikan agar diperoleh hasil yang lebih baik.

DAFTAR RUJUKAN

Arikunto, Suharsimi. 2002. DasarDasar Evaluasi Pendidikan. Kabupaten Kayong Utara: Bumi Aksara. 
Arikunto, Suharsimi. 2002. Prosedur Penelitian Suatu Pendekatan Praktek. Kabupaten Kayong Utara:Rineksa Cipta.

Combs. Arthur. W. 1984. The Profesional Education of Teachers. Allin and Bacon, Inc. Boston.

Dahar, R.W. 1989. Teori-teori Belajar. Kabupaten Kayong Utara: Erlangga.

Departemen Pendidikan dan Kebudayaan, 1994. Petunjuk Pelaksanaan Proses Belajar Mengajar, Kabupaten Kayong Utara. Balai Pustaka.

Djamarah, Syaiful Bahri. 2002. Strategi Belajar Mengajar. Kabupaten Kayong Utara: Rineksa Cipta.

Djamarah. Syaiful Bahri. 2000. Psikologi Belajar. Kabupaten Kayong Utara: Rineksa Cipta.

Hamalik, Oemar. 1994. Metode Pendidikan. Bandung: Citra Aditya Bakti.

Hamalik,Oemar. 2000. Psikologi Belajar dan Mengajar. Bandung: Sinar Baru Algesindo.

Kemmis, S. dan Mc. Taggart, R. 1988. The Action Research Planner. Victoria Dearcin University Press.
Margono. 1997. Metodologi Penelitian Pendidikan. Kabupaten Kayong Utara: Rineksa Cipta.

Ngalim, Purwanto M. 1990. Psikologi Pendidikan. Bandung: Remaja Rosdakarya.

Nur, Moh. 2001. Pemotivasian Siswa untuk Belajar. Surabaya. University Press. Universitas Negeri Surabaya.

Poerwodarminto. 1991. Kaтиs Umum Bahasa Indonesia. Kabupaten Kayong Utara: Bina Ilmu.

Purwanto, N. 1988. Prinsip-prinsip dan Teknis Evaluasi Pengajaran. Bandung: Remaja Rosda Karya.

Rustiyah, N.K. 1991. Strategi Belajar Mengajar. Kabupaten Kayong Utara: Bina Aksara.

Sardiman, A.M. 1996. Interaksi dan Motivasi Belajar Mengajar. Kabupaten Kayong Utara: Bina Aksara.

Sukidin, dkk. 2002. Manajemen Penelitian Tindakan Kelas. Surabaya: Insan Cendekia.

Suryosubroto, B. 1997. Proses Belajar Mengajar di Sekolah. Kabupaten Kayong Utara: Rineksa Cipta.

Syah, Muhibbin. 1995. Psikologi Pendidikan, Suatu Pendekatan Baru. Bandung: Remaja Rosdakarya. 